\title{
Study on the Phenomenon of Domestic Religion: The Implication in a Human's Identity and Consequences
}

\author{
Mariya Bicharova ${ }^{1, *}$ Anna Romanova ${ }^{2}$ \\ ${ }^{I}$ Caspian Institute of Sea and River Transport named after general admiral F.M. Apraksin the affiliation of \\ FSBEI HE "Volga State University of Water Transport", Astrakhan, Russia \\ ${ }^{2}$ Institute of Southern Russia and Caspian Region Studies at FSBEI HE "Astrakhan State University", \\ Astrakhan, Russia \\ "Corresponding author. Email: valkirija@inbox.ru
}

\begin{abstract}
The paper is devoted to the study of the "Domestic religion" phenomenon in modern real and virtual spaces, the role it plays in a modern human's identity development, and the consequences it may lead to. The term "Domestic religion/church" is far from new. The first mentions of the domestic church are found in the Old Testament but today the hash tag "domestic church" is quite popular on the Internet. It designates many blogs, websites and video channels that broadcast and publish posts on religious topics. They invite people to join their virtual community, and sometimes call for support to the authors of such resources in the form of donations or purchases of goods and services. We have studied in detail a number of sites and blogs under the hash tag "domestic church". We analyzed the topics of articles and videos as well as comments from Internet users subscribed to these resources. On the studied materials the typology is built. It is based on such criteria as presence or absence of commercial component, religious trend and mission. The results of the study show that the phenomenon of domestic religion in the virtual space is a manifestation of a human's virtual religious identity. As a consequence for a human or for the whole group of religious people, it can cause religious transgression of an individual both virtually and in real life.
\end{abstract}

Keywords: Human, Religion, Domestic religion, Domestic church, Religious identity, Religious transgression, Media space, Virtual community.

\section{INTRODUCTION}

The technological leap in the field of mass information made it possible to create a single space for communication for the whole world. Electronic media put on the back burner television, radio, print press, and books. It gave everyone not only unlimited access to any information, but also the opportunity for everyone to independently create information content. Earlier, the issues and broadcasts of traditional media used to be created by human-professionals, i.e. by journalists, editors, and technical personnel. Certain requirements were imposed on such content. They included at least the authority of the source (or even though its presence) as well as the reliability and objectivity of information. Nowadays, access-for-all availability blurs in fact the notion of source authority. Any ordinary person can be called a specialist in one area or another, a trainer, a coach, a leader, an ideologist, a consultant, etc. One can create his or her own website and promote some information, services or goods he needs. Taking into account the peculiar characteristics of individuals who are not professional media workers, even initially reliable information can acquire new semantic interpretations and emotional coloring, thus losing the opportunity to realize the goals and objectives that the media traditionally performed, and thereby losing the unity of message and perception. So, new interpretations of reality created by all and sundry have a significant impact on the formation of a perception picture and a picture of the world as a whole by consumers of this information. "Electronic media bring together scientific, aesthetic and ethical discourses, and in such a way that it is difficult to distinguish not only information from assessment, but also fiction from 
reality," says the Archpriest Georgy Yoffe, the Chairman of the Missionary Department of the St. Petersburg Diocese, in his report "Issues on the Definition of the Church language and Missionary Communication in the Media Space [1]".

The mass media are becoming a tool to manipulate individuals or entire masses. In the Internet space, people find like-minded people, close in spirit and outlook friends, and unite in communities, thus compensating for the lack of real communication and at the same time forming a new identity. Identity today ceases to be the result of genetic, physical, cultural, and intergenerational continuity. Today, it is a constructor that changes its shape and internal content under the influence of electronic resources, and it seems that a person himself becomes the creator of his identity deciding on his own what his social status is, what his role in society or his religious affiliation is.

The anonymity of electronic sources allows their authors to openly discuss any topic, raise the most acute and provocative problems which instantly become publicly available online. The possibility of open commenting enriches information with subjective and emotionally rich content. The ability to independently manage the content of an information resource, change it, comment, receive positive feedback, and manage comments causes quickly enough the dependence on electronic devices, and a person's real life is transferred to the virtual space.

The result of such processes is the emergence of a variety of thematic resources that unite followers around them. Among them, one can single out separate disparate information channels, blogs and religious sites created by different people, which are united by a thematic hashtag "domestic church".

The content of such resources is very diverse, however, they are united by the fact that any issue and any problem are viewed in terms of religion, and this is not always a traditional religion. Most often, the authors of such resources have their own unique understanding and interpretation of a particular issue using excerpts and quotes from some traditional religious dogmas. As a result, the resource serves a kind of a tool with the help of which an ordinary person promotes his or her own ideas or uses a religious background as a marketing ploy to promote his or her goods and services. Thus, the old theological term "domestic church / religion", which denotes a form of organization of religious life when believers gather for religious purposes at home in a family [2], acquires a completely different meaning in the modern information space. It is able to implicate in a human's identity and even have consequences for a group of people who transform their religious adherence under the influence of such Internet resources.

\section{DOMESTIC RELIGION IN THE PAST}

Let us take a closer look at the term "domestic religion" and try to understand how this concept could migrate into the modern media space. Let us think what its modern interpretation is and what features of traditional home religion are used by the authors of resources with the topic "Domestic church". Originally, the concept of "Domestic church" is found in the New Testament in the Epistles of the Apostle Paul [3]. It is very likely that the family itself is called the home church here. Matthew Henry, a 19th century English clergyman, notes:

"Note: Every Christian family must be, in a sense, a Christian church. Sometimes (such as when the family is in a foreign land where there are no other Christians) the family, if it is large enough, must be a church and fulfill all church regulations; but in ordinary cases they must live according to the rules of Christianity and conduct daily services" - this is the interpretation of the concept of "Domestic church" [4].

The Orthodox concept of the House Church [5] and the Catholic concept of the Chapel are connected with the concept of the Domestic church, but do not completely coincide. A Domestic Church can be composed of members of the same Christian family or a group of like-minded people who meet weekly for prayer. House church as a form of the Christian community has become most widespread in countries where Christianity is not the main religion.

Todd Asaad, the evangelist at Dallas FortWorth Church of Christ, speaks of house church as the most appropriate model for serving God:

"The Domestic church meeting model provided a direction-independent freedom that helped build a close and meaningful relationship with God and fellow believers as part of cultural change. ... The Domestic church was small enough that it fostered close relationships between people and united these people into one whole" [6]. 
In fact, the Domestic church which came into being at the beginning of our era gave an impuls to the emergence and widespread adoption of the Christian religion in the first three centuries.

In the book "Make All Nations Disciples. Small Group History and Church Growth Strategy", the author Galina Shteleh finds the prerequisites for the birth of Domestic churches in the first century AD, namely: the ideas of small groups in the Old Testament; the role of home in religious education in Jewish and pagan cultures; Jewish tradition of synagogues; the example of Christ and His command; apostolic theology of the "Church"; circumstances and expectation of the imminent coming of Christ [7].

We can also find the concept of "Domestis religion" in the book of the famous French historian Fustel de Coulanges "Ancient City. Religion, Laws, Institutions of Greece and Rome". In this book, the author comes to the conclusion that all more or less significant changes in the social life of Greece and Rome were caused by changes in the sphere of religious beliefs. F. Coulange devotes a whole chapter to the Domestic religion. We learn that in the era of ancient civilizations, the Domestic religion was considered nothing more than the cult of the dead. The first rule of it was that each family could worship only the dead who were their relatives by blood [8]. In fact, the Domestic religion was unique to each individual family. There were no single rules, no general ritual. Each family had its own religious rites which belonged only to it, its own prayers, and hymns [9]. The father, the only interpreter of religion and the only priest of the family, had the right to teach religion, but only to his son. Rituals, prayers, and hymns which constituted the main part of domestic religion were the ancestral heritage, the sacred property of the family which could not be shared with anyone. It was strictly forbidden to initiate outsiders into it. The latter fact distinguishes the Domestic religion of ancient civilizations from the Domestic religion of the New Testament period. It was the Domestic religion of the New Testament that went beyond the boundaries of a single family and began to gather like-minded people and followers around its preacher (pastor). Whereas the ancient domestic religion satisfied human needs such as family, unity, and worship, the home religion of the first three centuries AD added leadership and missionary development to this list. Teaching and preaching became an essential part of New Testament Domestic churches.
Elisa Novi Shavarria considers the term "Domestic religion" in a somewhat different way in her study "Domestic Religion and Connected Spaces: Isabella della Rovere, Princess of Bisignano". The author of this work studied the difficult fate of the princess of the Kingdom of Naples in the 16th century who was forcibly married to the richest feudal lord, Prince Bisignano. The princess's marriage was unhappy: she lost her only son, and in addition, her life was darkened by serious health problems that disfigured her appearance so she looked for consolation in religion. In addition to doing charity work, helping the disadvantaged and sick, supporting the Order of the Jesuits of Naples, giving them money, valuable objects, and fabrics and relics, she surrounded her own home space with various antiques, artifacts, paintings, and portraits of famous artists, often religious orientation, creating around itself the socalled "religious space".

"The Princess of Bisignano's domestic space ... represents both physical spaces and metaphorical spaces. They were spaces for intimacy and for prayer, for spiritual pain and for physical sickness. They were also spaces for sociability: aristocratic sociability in the Princess' court, with her lively social network consisting of cultural connections and exchanges of religious relics, scientific instruments, and artistic artefacts... [10]"

Princess Isabella's Domestic religion is a symbol of how forms of worship and devotion can cross social boundaries connecting the aristocratic milieu of Naples, Rome and Urbino, high-ranking members of religious orders and the humble followers of Brother Geremiah. This home devotion transcends national and local boundaries. It coexists in the same spaces where very different experiences and presences were felt. It reverses the traditional models of center and periphery. It is connected to other spaces and other historical actors and is constantly crossed by new agents and new adherents in a network that is in constant motion. It represents the triumph of the material culture of religious objects (religious images, rosaries, paternosti) and sensual and emotional experiences.

\section{DOMESTIC RELIGION TODAY}

In the modern media space, the terms "domestic religion" and "domestic church" are not uncommon, and often in personal blogs or Youtube channels devoted to religious issues, you can see the hashtag of the same name. However, the interpretation of this term by modern representatives of the clergy is 
somewhat different from its historical understanding. Thus, the popular American Internet resource Biblehub.com, created in 2004 and aimed at popularizing the Bible, translating scriptures into different languages of the world, as well as interpreting them, interprets the term "domestic religion" from the standpoint of Catholicism.

The creators of the resource have published an article by a certain Muston, from whose reasoning it can be understood that he identifies the term "Domestic religion" with the concept of "Family religion". Domestic religion, according to Muston, aims to create permanent well-being in the family. It is about following the canons of family religion, which are not only about fulfilling certain social and secular duties, but also about overcoming trials as evidence of patience and obedience to the will of God, bearing in mind the hardships and sorrows of family life, disappointment and loss that can be experienced by members of any family. Serving God is, according to the author of the article, what unites family members, creates social attachments, and contributes to the development of spirituality and morality:

"The worship and fear of God in families must directly tend to restrain the evil tendencies of those who are placed under authority, and to promote most effectually their spiritual welfare. Every household which duly recognises the authority of the supreme Parent in the stated exercises of devotion, is a most important school for the acquisition of the best principles and habits" [11].

From the point of view of Orthodoxy, the concept of the Domestic church is also considered in the aspect of family and family religion. The book of Archpriest Gleb Kaleda entitled "Domestic Church" is devoted to the interpretation of this concept. The author considers the building of a Domestic church to be the basis of the foundations of the existence of an Orthodox Christian in the world and in the Church. The book consists of essays in which the author tries to expound the Orthodox understanding of marriage, going back to the first centuries, and considers the ways of building a Domestic church in different historical conditions, essentially identifying the concepts of "family" and "domestic church". The author attaches great importance to this concept:

"Christianity always faces two tasks. The first, eternal, and internal is the acquisition of the Holy Spirit. The second is historical, and external. In the first centuries, such a task was the apostolate through martyrdom. In the IV-VIII centuries it was the disclosure of the eternal truth of Christ through preaching and dogmas. Later, it came to the raising of the people of God to grace and purity and their religious enlightenment through monasteries as centers of Christian asceticism and culture, etc. However, the monasteries themselves appeared much earlier. The building of Domestic churches is a historic challenge today. For the Russian Local Church, this is its entire future: if its members learn to create house churches, the Russian Church will exist, if they fail, the Russian Church will dry up" [12].

The Archpriest of the St. Elisabeth Convent in Minsk, Minsk Diocese of the Belarusian Orthodox Church, Andrey Lemeshonok, wrote:

"The Domestic church is a home where people who know God live. It is a house in which all relationships are based on love... This is the transformation of an apartment, earthly housing, into a temple. It is the labor of the soul that learns to love God through its neighbor. This is the desire of the soul to know the will of God and fulfill it. We live in a world that is hostile to God, hostile to the soul living with Christ.

The Domestic church is a fortress inaccessible to the enemy, a place where people come to warm themselves from the cold, unbelief, despair that reigns in the world. This is our view of our neighbor as a person whom the Lord has given us so that we can learn to love to the end. The Domestic church is a struggle with our sin, pride, with the unrighteousness that lives in us, because we do not want our sin to touch our neighbor [13]."

The information and analytical portal of the Saratov Metropolitanate defines the house church, first of all, as a family:

"The family is the Domestic Church. Saint Basil the Great also called the family a school of virtues. But the most important lesson a person learns in a family is a lesson in love. A family is unthinkable without love. Love having been brought up in a family must then leave its circle and spread to all spheres of social life. Without love for his family, for his country, a warrior is not a defender of the Fatherland, but only a mercenary. Without this love, there is no a real teacher, a doctor, or a scientist [14]." 


\section{4. "DOMESTIC CHURCH" IN THE MODERN MEDIA SPACE}

In this part, we will consider some examples of American and European media resources that have the word combination "Domestic church" in their title, or are designated by this hashtag.

Search request with the target phrase showed that there are many sites, blogs, Youtube channels, and social media accounts dedicated to religious topics. These are resources created by individuals (married women, mothers with many children, married or single men, clergymen, etc.), or by married couples who share their reasoning, thoughts, and life events, interpreting them from a religious point of view. Often they are talking about events taking place in the country and the world, or about pressing problems that worry most people (for example, the spread of the COVID-19 viral infection, feminism, US presidential elections, terrorism, homosexuality, parenting and education of children, etc.) Also, it can be just short posts about the everyday worries of a single family (going to the theater, school, crafts with children, etc.), again with religious overtones (for example, "look at how a Catholic family spends their weekends"). Such Youtube channels can have from 1 to 50 thousand subscribers from all over the world, and the number of video views can reach several million.

For example, the American married couple Bill and Nancy (last name not specified) first created a YouTube channel called "Catholic Sprouts", and then a site of the same name. The channel and site are completely dedicated to the Catholic religion and religious education and parenting. This is how their greeting looks like:

"Welcome to Catholic Sprouts, where we work to teach the truths of the Catholic Faith to children and inspire Catholic Mothers to be all God created them to be! Make sure to subscribe for the Daily, 5 minute podcast for kids. It will help you stay in tune with the liturgical calendar and plant one little seed of faith each day. Also, weekly we will be sharing videos to support and inspire Catholic Mothers as they do the good work on passing on the faith [15]."

The content of the posts boils down to topics related to faith in God, family, family values, religious education, etc. A separate video entitled "Domestic Church" is devoted to the interpretation of the concept of the Domestic church. In this video, Nancy talks about how their Internet project is the embodiment of the house church and encourages everyone to join the Catholic Sprout community. In is interesting that joining a community requires a monetary contribution. The rates are clearly described on the website, and the amount of the fee depends on the length of stay in the community from 1 month to 1 year. In addition, the authors of the community urge all visitors to make donations and transfer money to their account, even if they do not want to join the community. Another area of their activity is the publication of religious literature for adults and children, which is also sold on the site and, apparently, is a success among the followers of Catholic Springs. The community's Youtube channel was created in September 2018 and currently has 1.75 thousand subscribers.

Similar content has the Youtube channel "A Catholic Mom's Life" of the mother of many children Heather, who maintains a video blog on her behalf, talking about her love for God, how she likes to be a Catholic and how she builds her life and her life from the position Catholic faith:

"Hello thanks for stopping by my channel! I'm Heather and I'm a Catholic wife and mom of 3 boys and 2 girls!!! I hope my channel will inspire others to grow more in love with God! I will be sharing all kind of videos from faith, testimonies, lifestyle, NFP, family, fashion, homemaking, clean with me, children, marriage, recipes and even some Catholic vlogs here and there. Hope you subscribe and enjoy [16]!!!"

Heather's videos are mainly related to religious themes. Some titles include: "Do's and Don'ts for a Catholic Mass", "For the First Time at a Catholic Mass", "How to Go to Mass", "Catholic Mom", "I Love Being Catholic!", "My Home Catholic Altar", "Catholic Etiquette for Beginners", "What Should Be in Every Catholic Home", "Confession. How and why to go to confession","5 things that all good Catholics should do".

In each video, a woman speaks about her faith with inspiration, receives many positive comments not only from her fellow believers, but also from representatives of other religious denominations. Her emotional speeches, judging by the comments, are even able to motivate the audience to convert from one faith to another. Here are some comments from users who viewed Heather's video:

"Great video, Heather! You mentioned the people trying to convert you, but now tell us... how many people have come to you and told you that 
they converted to Catholicism because they were inspired by your videos?? I am willing to bet there are many!! Thank you for the beautiful mission you live out and keep up the good work! God bless you!"

"Thank you for being so open and honest about why you love being Catholic. I'm new to the church and joined because of the reasons you stated. There is just an overwhelming peace sitting in the church participating in the mass. I don't feel like a service is happening around me but that I am fully engaged during mass. That's what I love. You are a blessing to watch and I'm so happy I found your channel".

"Hay 1 am a 13-year-old teenager from Sri Lanka who was born a Buddhist but found Salvation i got baptized last week into the catholic church your videos helped me a lot thanks plz pray for the Sri Lankan catholic community we are just a small church God bless u [17]".

All the comments mentioned above prove to be the positive examples of religious communication and transformation.

The author of the channel, like the previously mentioned married couple, publishes religious literature, mainly for children and sells it on the Amazon.ru website. She actively encourages her subscribers to purchase literature in each of her videos. Heather's channel was created in March 2017 and today has more than 46 thousand subscribers.

But not all blogs, websites and Youtube channels are admired and approved by Internet users. So, interesting in its content is the Internet page of two friends, Raylan Alleman and William Jill, called "Fix the Family":

"Fix the Family is a lay Catholic Apostolate formed to aid and support Catholics, married or aspiring to marriage, in making their marriages rock-solid and raising their children to be strong in their Catholic Faith empowering them to resist the pull away from the Church by emphasizing authentic masculinity and femininity and offering a practical application of the solid teachings of the Catholic Faith. Disclaimer: No content presented by Fix the Family or Citadel Catholic Media violates or contradicts Official Catholic Church Teaching, Dogma, or Doctrine. Further, content is based on such Teaching and is frequently and appropriately referenced in the content itself. Content presented is an Application of such teaching as has been practiced for centuries and generations placed in a context of contemporary living. That being said, not everything presented and recommended is necessarily required under the pain of $\sin [18] "$.

The authors maintain a video blog on the Youtube channel, discussing topical issues through the prism of scripture, and the idea of gender superiority of men over women runs through all their discussions, which is extremely unhappy with the female part of users watching the video. So, in one of the videos, the authors, discussing the role of women in society, began to say that motherhood and household are all that a woman should do - no career and no money making, for which they received many negative reviews not only from the outside women, but also men, for example:

"I disagree that women should necessarily completely forfeit careers to stay home. I am a quadriplegic in need of 24-hour care and nurse visits. I only have female nurses and attendants. In other words it's a job men can't do. Many of my nurses are married and happily so. They aren't the bitter picture you present. I think you represent as Catholic teaching your rigid views which aren't necessarily Catholic. Also, not all women get married so they should prepare for careers [19]".

Despite the criticism, the channel "Fix the Family" created more than 10 years ago has its subscribers - about 3 thousand people who write positive reviews and comments with gratitude for blogging.

Even more controversial, we find the blog www.davidservant.com authored by a certain David who introduces himself as a minister of the Catholic Church and founder of the non-profit organization Heaven's Family. The blog's welcome note says that the site covers David the Minister's Bible study activities. He exists to serve God seekers, people who want to follow Jesus [20].

The topics that the author of the blog touches on in his articles can often be described as shocking, those that are not accepted to be discussed in the framework of religious discussions: "A homosexual you will love", "I love homosexuals, and I'm frustrated", "What does the Bible say about oral and anal sex?", "Trump is god's man (... and so was Obama)", "Is it a sin not to vote, or is it a $\sin$ to vote?", "I've had an abortion. Will god forgive me?", "What Jesus taught about stewardship and money", "What does the bible say about interracial marriage?"

A distinctive feature of this blog from all the other sites, blogs, and channels we reviewed is that it completely excludes the presence of comments 
and user reviews. There is only a feedback form that allows the user to send a message to the site owner, but the content of this message will remain inaccessible to other users. In this regard, it is quite difficult to assess the popularity of the site, as well as the attitude of users to its content. We can only assume that the author is not sure that the reviews will be positive, and therefore ruled out the possibility of openly commenting on his articles. The financial component on this site, however, is presented in full: the author suggests making donations to support himself, as well as various suffering, homeless and orphans. In addition, the site has a separate tab called "Shop" where religious literature published by the author of the site is sold.

It should be said that not all Internet resources listed under the name or hashtag "Domestic religion" are aimed at receiving support from users in the form of fees and monetary donations. For many authors of blogs on Youtube channels, Domestic religion, as well as for the Neapolitan princess of the 16th century Isabella della Rovere, is a way to share their experiences and sorrows, a kind of outlet, an alternative to keeping a personal diary, access to which Internet users have access and can comment on an article or video, empathize, support, and give useful advice. The authors of such resources do not ask for financial support and do not have a large number of subscribers. They simply blog, primarily for themselves, and for them this is their personal "Domestic church".

Having analyzed many Internet resources the authors of which, in one way or another, identify their online activities with home religion we can try to build a typology of such "virtual domestic churches" based on several criteria. The first and most obvious criterion, in our opinion, is the presence or absence of a financial component. The question is whether the collection of donations, admission fees, donations is included in the activities of such Internet communities, or the sale of goods and services is carried out. From the examples described above, we saw that the authors of many resources with the hashtag "Domestic religion" build their so-called "missionary activity" solely based on the financial support of their subscribers. At the same time, it can be noted that some video blogs and Internet pages operate completely without financial support from their few subscribers. Thus, we divide the Internet resources "Domestic Religion" into commercial and noncommercial.
Another criterion for typologizing the resources "Domestic Religion" can be their belonging to a particular confession. So, for American resources, Catholic home religions are characteristic, for European (Great Britain and France) - Protestant ones (for example, Campus protestant, Hanna Mekonen OFFICIAL Channel). Slavic authors of Internet resources from countries such as Russia, Ukraine and Belarus preach the Orthodox religion more often (for example, Father Vladimir Golovin, Monk Evlampy, Father-Dusha, Evgeny Vladimirovich Drachilovsky). In addition, from different parts of the world, apparently, representatives of the Jewish Diasporas maintain video blogs about Judaism (for example, Shalom Television, JewishLife, El Shalom). It is interesting to note that there are very few private Internet resources devoted to Islam. We managed to find only a couple of video blogs broadcasting cartoons on themes from the Quran (IQRA CARTOON Islamic Prophets \& Quran Stories, Omar \& Hana Islamic Cartoons for Kids, as well as a small Youtube channel dedicated to the study of Islamic religion (Quran Tutorials Online). Thus, based on religious affiliation, we subdivide Internet resources under the hashtag "Domestic religion" into Catholic, Protestant, Orthodox, Islamic, Judaic, etc.

The third criterion according to which it is possible to build a typological model of virtual domestic churches is mission. It is easy to see that different authors of video blogs, websites and Internet pages see the essence of their virtual activities differently. For some, the educational component of the content is important. These are sites aimed at popularizing a particular religious trend, highlighting important historical facts and events, traditions, religious holidays, etc. Some authors literally preach on the Internet. They are talking about videos and articles devoted to various household, social, cultural, and political problems, which are viewed through the prism of religious doctrine. Finally, the most information-aggressive, in our opinion, are the authors of resources aimed at increasing the number of followers of a particular religion. These are sites and video blogs that openly promote a particular religion and urge users to abandon their religion and turn to a new one. Thus, based on the mission of the site or video channel, designated by the hashtag "Domestic religion", we divide them into educational, preaching and propagandist Internet resources. 


\section{CONCLUSION}

The modern virtual space is rapidly absorbing all social trends, phenomena and tendencies becoming a powerful and effective instrument of human social institutions, as well as a translator of values, norms, and laws of society. Religion, which has become an integral part of the virtual world, is no exception: both official representatives of all world confessions, as well as individual religious and pseudo-religious organizations, sects and cult communities have taken their positions in the global network, joining in the virtual struggle for the number of their followers. Even such an ancient phenomenon as "Domestic religion" albeit in a transformed form has found its place in the modern media space. This phenomenon is not only the subject of discussion on the Internet by scientists, clergy, and ordinary people, such as bloggers, but has itself become a part of the virtual space.

One of the Russian bloggers Yaroslav Terletsky who maintains a page on the Internet on religious topics and positions himself as a Domestic church preacher studying this phenomenon comes to the following conclusions:

"Domestic churches have always had many benefits.

- A) Since there are usually not many people in such churches, everyone knows the needs, and the spiritual state of each other. This makes it possible to notice them in a timely manner and provide assistance.

- B) The majority of the believers were employed in the Domestic church.

- C) It was more convenient to invite unbelievers to the meeting.

Of course, today we have the opportunity to have large Houses of Prayer and this is very good but practice shows that home groups during the week are a very good method for both evangelism and growth in the faith of church members. It may be difficult to get together once a week, but once a month, as we received in our church, it has become a very good custom [21]".

Having studied the history of the origin of domestic religion and examining modern interpretations of scientists and representatives of the clergy of this phenomenon, we cannot fail to see a clear similarity of that Old and New Testament home religion with modern Internet communities, designated by the key phrase "domestic religion". First, it is the identification of the family and the home church. On the one hand, domestic religion is a way of uniting all family members, creating peace and quiet, something holy and sacred that strengthens the spirit and unity in the family. On the other hand, it is an invitation to all members of the virtual community to become part of this spiritual unity. Thus, the modern Domestic church in the media space can be called a tool for the formation of a virtual religious identity, which is a reflection of real human (personal, collective) identity, strengthening it in the field of virtual communication [22].

For some people, "Domestic religion" in the virtual world is also a way to demonstrate and broadcast their religious identity, which makes it possible, on the one hand, to self-identify with one or another religious community, on the other, to feel their originality and uniqueness, or even try yourself in the role of a shepherd, spiritual mentor, preacher, helping other people find themselves in this world [23]. Thus, we can assert that the activity of the virtual communities "Domestic Religion" can also be the cause of religious transgression, which can occur not only virtually, but also in real life. Let us recall the comments on the video blog of the American mother of many children, Heather, who in her videos tells with inspiration how she likes to be a Catholic, thereby encouraging many representatives of other religious faiths to change their faith to Catholic.

The modern virtual "Domestic church" has acquired new features inherent in today's trade and commercial relations in any sphere of society [24]. Many blogs and video channels conduct their "missionary" activities backing it up with a financial component. The authors of such resources urge Internet users to provide financial assistance, make charitable donations, or purchase products that are presented on the site (most often religious literature for children and adults). On the one hand, this seems quite logical, since the support and maintenance of any Internet resource requires money; on the other hand, the modern domestic church in the virtual space seems to us just another "store of spiritual services", where a human comes and for a certain fee "satisfies his spiritual needs".

\section{AUTHORS' CONTRIBUTIONS}

Prof. A. Romanova devised the project and the main conceptual ideas. Associate Prof. M. Bicharova designed the study and proof outline. Besides, M. Bicharova developed the theoretical formalism, performed the content analysis and with 
the help of A. Romanova conducted the interpretation of the results. A. Romanova encouraged M. Bicharova to create the typology of sources investigated. M. Bicharova took the lead in writing the manuscript in consultation with A. Romanova and contributed about eighty per cent to the paper.

Both authors contributed to the final version of the manuscript. A. Romanova supervised the project and contributed about twenty percent to the whole paper.

\section{ACKNOWLEDGMENTS}

The study was carried out by a grant from the Russian Science Foundation (Project No. 18-7810064) "Transformation of mechanisms of formation of post-transgress model of religious identity in the modern information space".

\section{REFERENCES}

[1] G. Joffe, The Issues of defining the language of the Church and missionary communication in the media space, Proceedings of the conference "Church in the media space", 17.06.2017, Russian Orthodox Church, St. Petersburg, http://missia-spb.ru/tserkov-vmedijnom-prostranstve/, accessed on 15.01.2021.

[2] V. S. Bezrukova, Fundamentals of Spiritual Culture, Encyclopedic Dictionary of a Teacher, Ekaterinburg, 2000, 937 p.

[3] 1 Corinthians. 16:19

[4] H. Matthew, The all books of the New Testament interpretations, Vol. 1.: Dutch Reformed Tract Society, 2002, 405 p.

[5] Orthodox Encyclopedia. 2007, M.: Church Scientific Center "Orthodox Encyclopedia". Vol. XV. 752 p.

[6] T. Asaad, House Church in Christian History and the New Testament, 2010, https://icocnews.ru/duhovnayazhizn/leaders/domashnie-tserkvi-v-istoriinovogo-zaveta.html, accessed on 15.01.2021.

[7] G. I. Shtele, Make disciples of all nations. Small group history and church growth strategies, 2nd ed. rev. and add. Zaoksky: "The Source of Life", 2003, p.25.
[8] F. Coulanges, Ancient City. Religion, Laws, Institutions of Greece and Rome, M.: ZAO PH Centrpoligraf. p. 33.

[9] A. M. Chelsea, Gardner Revealing Domestic Religious Practice: A Study of the Distribution of Private Altars in Olynthus: the report of study, Social Sciences and Humanities Research Council of Canada, The University of British Columbia, 2020, p. 1

[10] E. N. Chavarria, Domestic Religion and Connected Spaces: Isabella della Rovere, Princess of Bisignano, Domestic Devotions in Early Modern Italy, Koninklijke Brill NV, 2019, p. 158.

[11] C. R. Muston, Domestic Religion, The Biblical Illustrator, Electronic Database., https://biblehub.com/sermons/auth/muston/do mestic_religion.htm, доступ от 15.01.2021.

[12] G. Kaleda, Domestic Church, Publishing house: Conception Monastery, 1998, 203 p.

[13] A. Lemeshonok, What is domestic church? Meeting, No. 21, 2020, https://obitelminsk.ru/chitat/den-za-dnyom/2018/chtotakoe-domashnyaya-cerkov, accessed on 15.01.2021.

[14] D. Kamenshchikov, Domestic Church, Orthodoxy and Modernity: Information and Analytical Portal of the Saratov Metropolitanate, 2011, https://pravoslavie.ru/47517.html, accessed on 15.01.2021.

[15] Electronic Source: https://www.youtube.com/channel/UCnxnyr_ ks8gLT16HbJEfzug/ about, accessed on 15.01.2021.

[16] Electronic Source: https://www.youtube.com/channel/UCBPwe6 1hWru6AN8ZzyY-KwA/about, accessed on 15.01.2021.

[17] Electronic Source: https://www.youtube.com/watch?v=uu82Ggn BzP0, accessed on 15.01.2021.

[18] Electronic Source: https://www.youtube.com/user/citadelcatholic media/about, accessed on 15.01.2021.

[19] Electronic Source: https://www.youtube.com/watch?v=31GdV9fl kM4, accessed on 15.01.2021. 
[20] Electronic Source: https://www.davidservant.com/start-here/, accessed on 15.01.2021.

[21] J. Terletsky, Domestic churches in the New Testament, LiveJournal, https://blogchristian.livejournal.com/68035.html, accessed on 15.01.2021.

[22] A. P. Romanova, and D. A. Chernichkin Problems of virtual religious identity, Political Science. № 4, 2020, pp. 59-73.

[23] E. Khlyshcheva, V. Dryagalov, M. Topchiev, A. Romanova, and M. Bicharova Features of the virtual religious space formation in the conditions of the cultural border of the southern outpost of Russia, International Journal of Scientific and Technology Research, 2020, 9(1), p. 1257.

[24] R. Gianarkis, Spiritual but not religious: on the collection of spirituality and the creation of spiritual narrative, Hofstra University, 2013, p. 39. 